\title{
Role of Regulatory Domain Mutants of PKC Isoforms in c-fos Induction
}

\author{
Julhash U. Kazi and Jae-Won Soh \\ Bionedical Research Center for Signal Transduction Vetworks. Department of Chemisty. Inha Chiversin. \\ Incheon 402-751. Korea. *E-mail: sohiäinha.ac.kr \\ Received October 6, 2007
}

Key Words : TPA, Cdc+2. Racl. RhoA. SRE

Protein kinase $\mathrm{C}$ (PKC) is a multi-gene family of serinethreonine protein kinases. composed of at least 10 kinases. ${ }^{1}$ Classical and novel PKC isoforms are activated by diacylglycerol (DAG) and induce survival pathways in various cells. A tandem repeat of cysteine-rich motif referred to as the Cla and Clb domain in the regulatory domain is thought to be responsible for this activation. Atypical $\mathrm{PKC}$ isoforms. which lack of the $\mathrm{Clb}$ domain. cannot be activated by $\mathrm{DAG}^{1}$ A DAG analog 12-O-tetradecanoylphorbol-13-acetate (TPA) is known to activate PKC. resulting in diverse cellular functions such as cell proliferation. differentiation and tumorigenesis. PKC can activate extracellular signal-regulated kinase (ERK) through mitogen-activated protein (MAP) kinases. Activated ERK translocates to the nucleus and regulates the activity of many transcription factors. ${ }^{2}$ Tennary complex factor (TCF) is one of the most studied transcription factors in this pathway ${ }^{3}$ and is involved in c-fos transcription. ${ }^{4} \mathrm{c}$-fos is a proto-oncogene belonging to the immediate early gene family of transcription factors. and is involved in cell proliferation. differentiation and progression of cancer. ${ }^{5}$ The serum response element (SRE) in the c-fos promoter is required for the induction of c-fos gene. ${ }^{\circ} \mathrm{TCF}$ and another transcription factor. serum response factor (SRF) bind to SRE and activate the transcription.

The Rho family small GTPases including Rho proteins (RhoA and RhoB), Racl, and Cdc42, are members of the Ras superfamily of GTPases. These GTPases regulate many biological processes. including cell proliferation. differentiation, cytoskeletal regulation. membrane trafficking. cell adhesion. cell polarization, and transcriptional activation. ${ }^{7}$ Rho family GTPases can activate serum response factor (SRF). resulting in cell proliferation. Recently we have shown that the regulatory domain mutants of specific PKC isoforms induced apoptosis in breast cancer cells. ${ }^{s}$ Here we studied the effect of regulatory domain mutants of PKC isoforms in transcriptional activation of c-fos gene.

We and several investigators demonstrated that TPA induces transcriptional activation of the c-fos gene in a PKCmediated pathwar. ${ }^{3.11}$ To explore the role of the regulatory domain nutants of $\mathrm{PKC}$ isoforms in this pathway. we used expression plasmids. pHAN1-PKC $\alpha$-REG pHAN1-PKC $\delta$ REG pHAN1-PKC $\varepsilon$-REG and pHANI-PKC 5 -REG which encode regulatory donain mutants of $\mathrm{PKC} \alpha \mathrm{PKC} \delta, \mathrm{PKC} \varepsilon$ and $\mathrm{PKC} \zeta$ respectively. Western blot analyses after transient expression of these mutants in NIH3 3 mouse fibroblast cells. showed expected sizes of each constructs and similar
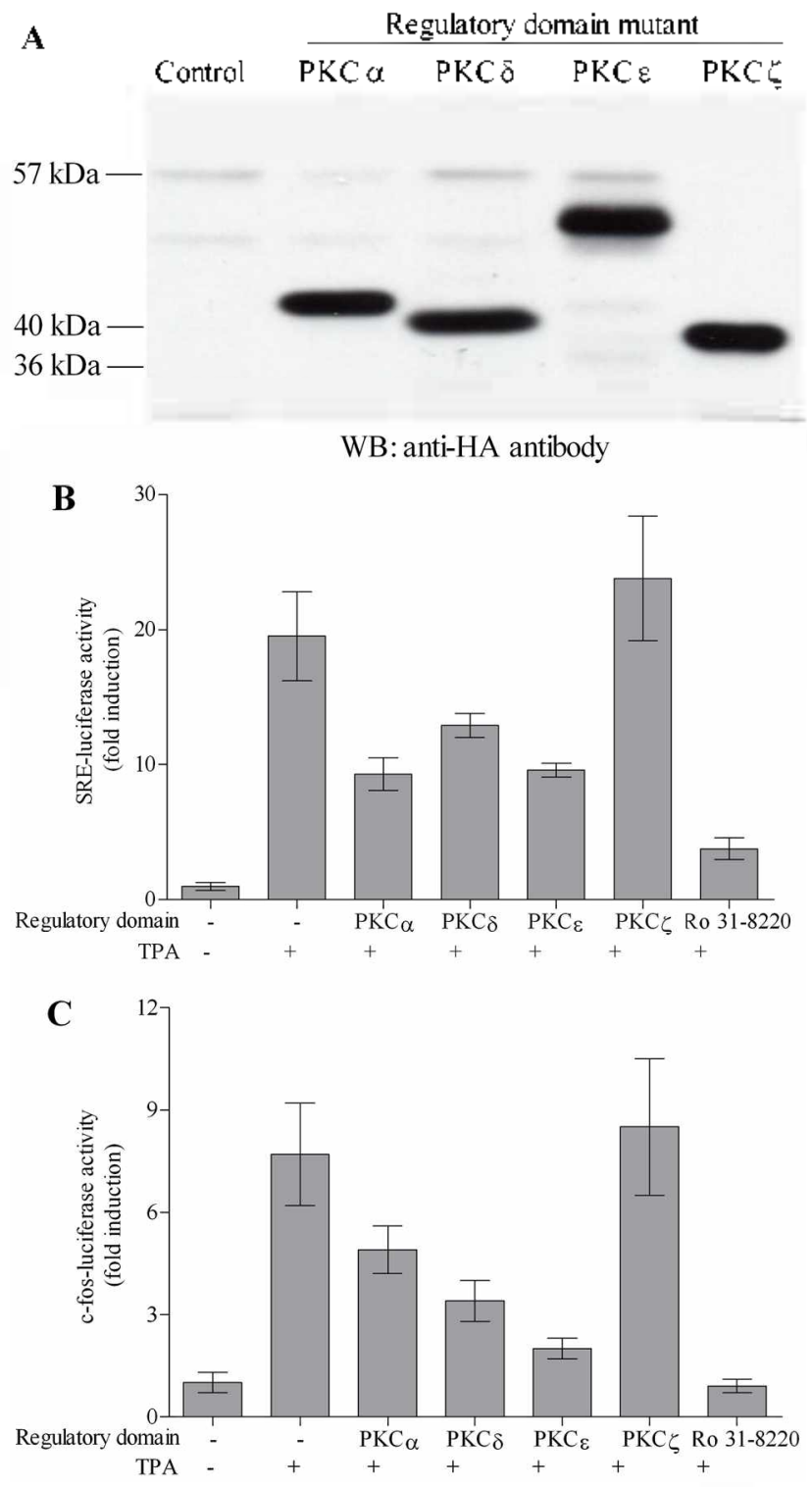

Figure 1. Role of regulatory domain mutants of $\mathrm{PKC}$ isoforms in TPA-mediated c-fos induction. COS-7 cells were transtected with pHANl-PKC $\alpha$-REG, pHANI-PKC $\delta$-REG, pHANl-PKC $\varepsilon-R E G$, pHANl-PKC $\zeta$-REG or pcDNA3 and cellular proteins were extracted by cell lysis. Westem blotting was perfonmed using antiHA-antibody (A). NIH3I3 cells were cotransfected with pSRE-luc (B) or ptos-WT-luc (C) reporter plasmid ( $\mathrm{l} / \mathrm{g}$ ) and pHANIPKC $\alpha$-REG, pHANl-PKC $\delta$-REG, pHANI-PKC $\varepsilon$-REG pHANIPKC C-REG or empty control vector. The cells were then serum starved for 24 hours and treated with either $0.1 \%$ DMSO or $100 \mathrm{ng} /$ $\mathrm{mL}$ TPA for 3 hours and assayed for luciterase activities. 
expression levels (Fig. 1A).

Using transient transfection assays with SRE luciferasereporter plasmid (pSRE-luc) in NIH3T3 mouse fibroblast cells. we found that TPA-induced SRE activation was partially blocked by the regulatory domain mutants of $\mathrm{PKC} \alpha$ $\mathrm{PKC} \delta$ and $\mathrm{PKC} \varepsilon$ but not by the regulatory domain mutant of PKC $\zeta$ (Fig. IB). These results suggest that regulatory domain mutants of PKC isoforms act as a dominant-negative form in our transient transfection assays. Failure to block TPA-mediated signaling pathway by the regulatory donain mutant of $\mathrm{PKC} \zeta$ is consistent with previous reports that PKC $\zeta$ lacks TPA binding domain and thus is not responsive to DAG or TPA. ${ }^{\text {I2 }}$ TPA-induced SRE activation was only partially inhibited $(30-50 \%)$ by individual regulatory domain mutants and was further inhibited dramatically by the combination of the regulatory donain mutants of $\mathrm{PKC} \alpha$ $\mathrm{PKC} \delta$ and $\mathrm{PKC} \varepsilon$ (data not shown). and non-selective PKC inhibitor Ro $31-8220$ (Fig. IB). Use of c-fos luciferase

A

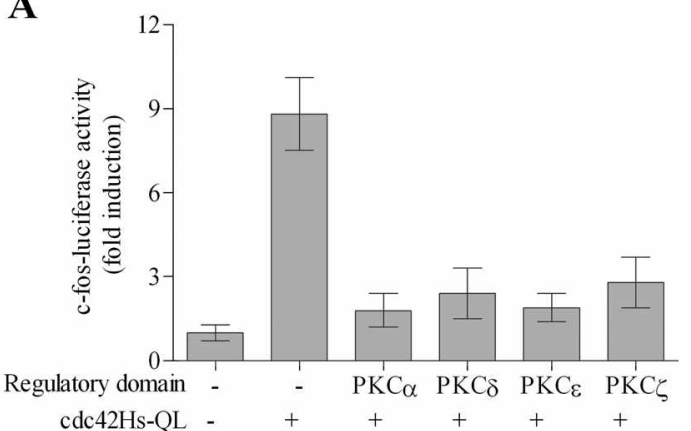

C

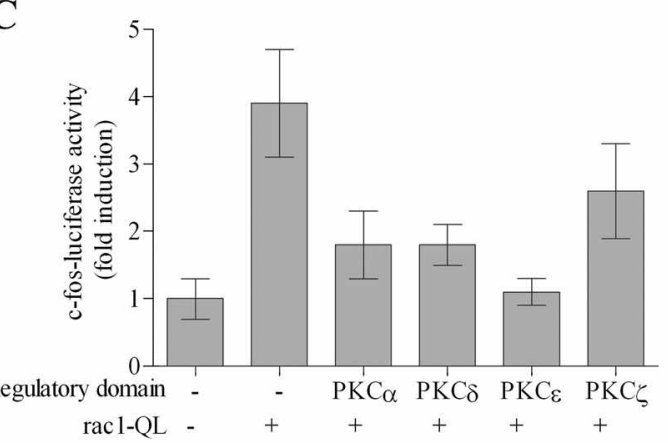

$\mathbf{E}$

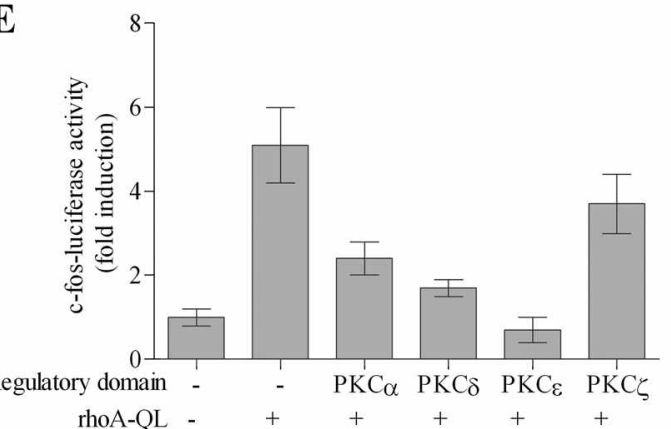

reporter plasmid (pfos-WT-luc) further supports these findings (Fig. IC).

Since PKC and Rho family small GTPases were reported to be involved in SRE activation. ${ }^{13}$ we examined the effect of regulatory domain mutants of $\mathrm{PKC}$ isoforms in this pathway. NIH3T3 cells were cotransfected with luciferase reporter plasmids (pfos-WT-luc or pSRE-luc). constitutively active mutants of Rho family GTPases ( $p c D N A 3 B-c d c 42 \mathrm{Hs}$ Q6IL or pcDNA3-racl-Q6IL or pCMV-rhoA-Q63L). and regulatory domain mutants of $\mathrm{PKC}$ isoforms (pHANlPKC $\alpha$-REG pHANl-PKC $\delta$-REG pHAN1-PKC $\varepsilon$-REG and pHAN1-PKC $\zeta-R E G$ ) or empty control vector (pcDNA3). SRE activation or $\mathrm{c}$-fos induction mediated by the constitutively active mutants of Rho family small GTPases was mostly inhibited by the regulatory domain mutants of $\mathrm{PKC} \alpha$ $\mathrm{PKC} \delta$, PKC $\varepsilon$ and $\mathrm{PKC} \zeta$ (Fig. 2). These results suggest that PKC isofomms are the downstream effectors of Rho family GTPases and the regulatory domain mutants of PKC iso-

B

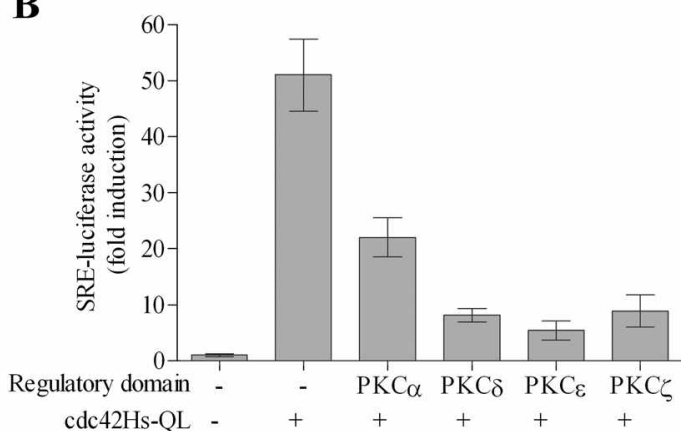

D
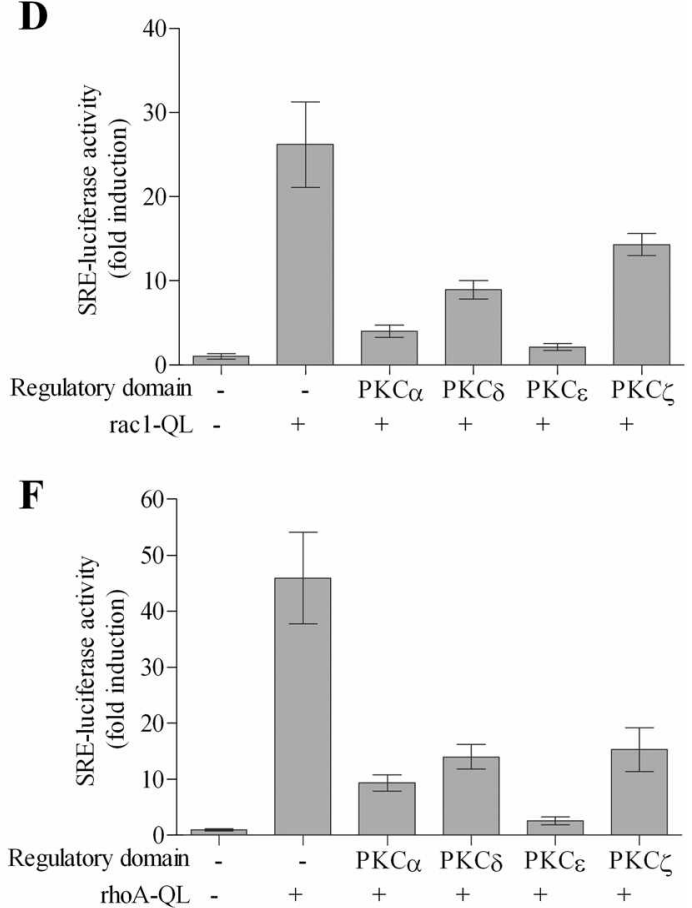

Figure 2. Role of regulatory domain mutants of PKC isoforms in GTPases-mediated c-fos induction. NIH3T3 cells were cotranstected with pfos-WT-luc or pSRE-luc reporter plasmid ( $1 \mu \mathrm{g})$, pHAN1-PKC $\alpha$-REG, pHAN1-PKC $\delta$-REG, pHAN1-PKCE-REG, pHAN1-PKC 6 -REG or empty control vector and paDNA3B-cde42Hs-Q61L, peDNA3-racl-Q61L, pCMV-rhoA-Q63L or empty control vector. The cells were then serum starved for 24 hours and treated with $0.1 \%$ DMSO and assayed for luciferase activities. 
forms inhibited c-fos induction by blocking the Rho-SRF pathway.

In conclusion. the results of this study suggest that regullatory domain mutants of $\mathrm{PKC}$ isoforms inhibited TPA or constitutively active mutants of Rho family GTPases mediated transcriptional activation of $\mathrm{c}$-fos gene by blocking the activation of endogenous PKC isoforms. This observation further provides the evidence that PKC isoforms might be a good target for developing anti-cancer agent in tumor growth.

\section{Experimental Section}

Plasmids. Luciferase reporter plasmids, pSRE-luc and pfos-WT-luc and constitutively active mutant of rohA. pCMV-rhoA-Q63L were described previously. ${ }^{3}$ Expression vectors for the regulatory donains of $\mathrm{PKC}$ isoforms, $\mathrm{pHANI}$ PKC $\alpha$-REG pHANI-PKC $\varepsilon$-REG and pHAN1-PKC $\zeta$-REG were also described previously. ${ }^{8}$ pHANI-PKC $\delta$ REG expression plasmid was constructed by subcloning the EcoRI fragment of regulatory domain of $\mathrm{PKC} \delta^{\text {is }}$ into $\mathrm{pHANl}$ vector. ${ }^{8}$ pcDNA3-rac1-Q61L. pcDNA3B-cdc42Hs-Q61L were also described previously. ${ }^{10}$

Cell transfection. NIH3T3 cells were grown in DMEM containing $10 \%$ calf serum. Triplicate of $1 \times 10^{5}$ cells in 35 $\mathrm{mm}$ plates were transfected by lipofectin (Gibco BRL) with $2 \mu \mathrm{g}$ of reporter plasmid, 2 or $5 \mu \mathrm{g}$ of expression vectors. and $1 \mu \mathrm{g}$ of pCMV- $\beta$-gal. pcDNA3 plasmid DNA was added to the transfections as needed to achieve the same amount of plasmids per transfection. COS-7 cells were grown in DMEM containing 10\% FBS. $2 \times 10^{5}$ cells in 60 $\mathrm{mm}$ plates were transfected by lipofectin (Gibco BRL) with $5 \mu \mathrm{g}$ of expression vectors or control vector pcDNA3.

Luciferase reporter assay. Six hours after transfection. cells were fed with new media (DMEM with $10 \%$ calf serum). left overnight, then serum-starved for 24 hours in DMEM with $0.5 \%$ calf serum. For TPA experiments. cells were treated with either or TPA for 3 hours to make a final concentration of $100 \mathrm{ng} / \mathrm{mL}$. DMSO was used as a control. Luciferase Assays were performed with senum-staryed or TPA-treated cells using the Luciferase Assay Sy'stem (Promega). Luciferase activities were normalized by $\beta$-gal activities. $\beta$-gal assays were performed using the $\beta$-Galactosidase Enzyme Assay System (Promega).

Transient expression of PKCs in COS-7 cells. Six hours after transfection. cells were fed with DMEM with $10 \%$ fetal bovine serum and left overnight. Cells were then transferred to $10 \mathrm{~cm}$ plates and grown for 24 hours before protein extraction. Cellular proteins were extracted by cell lysis in RIPA buffer $(50 \mathrm{mM}$ Tris $\mathrm{HCl}, \mathrm{pH} 8.0 .150 \mathrm{mM} \mathrm{NaCl} .1 \%$ NP-40. $0.1 \%$ sodium dodecylsulfate, $0.5 \%$ deoxycholate. 2 mM EDTA. $2 \mathrm{mM}$ EGTA. $1 \mathrm{mM}$ dithiothreitol) containing protease inhibitors $(10 \mu \mathrm{g} / \mathrm{mL}$ aprotinin. $10 \mu \mathrm{g} / \mathrm{mL}$ leupeptin. $0.1 \mathrm{mM} \mathrm{PMSF}$ ) and phosphatase inhibitors ( $1 \mathrm{mM} \mathrm{NaF}$. $0.1 \mathrm{mM} \mathrm{Na} \mathrm{VO}_{4}, 10 \mathrm{mM} \beta$-glycerophosphate). Fifty microgram aliquots of total cell extracts were subjected to SDSPAGE. Proteins were then transferred to Inmobilon-P (Millipore) at $60 \mathrm{~V}$ for 3 hours at $4^{\circ} \mathrm{C}$. Membranes were subsequently blocked with $5 \%$ dry milk in TBS-T ( $20 \mathrm{mM}$ Tris $\mathrm{HCl}, \mathrm{pH} 7.6,137 \mathrm{mM} \mathrm{NaCl}, 0.05 \%$ Tween-20), and then probed with an anti-HA antibody HA.ll (Covance) with 1:1000 dilution. Inmunoblots were visualized with the Enhanced Chemiluminescence Western Blotting System (Amersham).

Acknowledgments. This work was supported by an INHA UNIVERSITY Research Grant.

\section{References}

1. Newton. A. C. Biochent, J. 2003. 370.361

2. Lee. Y. J.: Soh, J. W: Jeoung. D. I.; Cho, C. K.: Jhon, G. J.; Lee, S J.; Lee, Y. S. Biochim. Biophys. Acta 2003. 1593, 219.

3. Soh. J. W.: Lee. E. H.: Pryes. R. Weinstein. I. B. Hol Cell Biol. 1999. 19. 1313 .

4. Li. W: Whaley. C. D.: Bonnevier. T. L.: Mondino. A.: Martin. M E.: Aagaard-Tillery. K. M.: Mueller. D. L. J. Immmol 2001.167. 827.

5. Milde-Langosch, K. Eur, J. Cancer 2005, 11, 2449.

6. Treisman. R. Trends Biochem. Sci. 1992, 17.423.

7. Burridge. K.: Wennerberg. K. Cell 2004. 116. 167.

8. Soh. T. W. Lee. Y. S.: Weinstein. I. B. J. Exp. Thet: Oncol. 2003. 3.115.

9. Lee. Y. J.: Lee. D. H.; Cho, C. K.: Bae. S.: Jhon. G. J.: Lee. S. J.; Soh. J. W.: Lee, Y. S. J. Biol. Chem 2005, 280, 18108

10. Coso. O. A.: Chiariello, M.: Yu. J. C.: Teramoto, H.: Crespo. P: Xu. N.: Miki. T.: Gutkind. J. S. Cell 1995. 81. 1137.

11. Oh. T.: Rhee. H. T.: Kim. S.: Kim. S. B.: You. H.: Kim. T. H.: Na. D. S. FEBS Lett. 2000. 477.244

12. Kim. S. J.: Chang, Y. Y: Kang. S. S.: Chun, J. S. Biochem Biophus. Res. Conmun. 1997. $237,336$.

13. Choi, S. E.; Choi. E. Y; Kim, P. H.; Kim. J. H. Cell Signal 1999. 1]. 71 